\title{
Performance Efficiency Of Zakat Management Organization (OPZ) In Indonesia
}

${ }^{1}$ Mohamad Andri Ibrahim, ${ }^{2}$ Intan Manggala, ${ }^{3}$ Wijayanti Eva Fauziah, ${ }^{4}$ Dina Gustriana, ${ }^{5}$ Nadya Az-Zahra

14 Program Studi Perbankan Syariah, 2,3 Program Studi Muamalah, Fakultas

Syariah Universitas Islam Bandung

Jalan Tamansari No 24 Kota Bandung

Email: andriibrahim@unisba.ac.id, intanmanggala267@gmail.com, evafauziah@unisba.ac.id, dinagustriana@gmail.com nadyahzra@gmail.com Received: 21 Oktober 2021; Revised: 18 November 2021; Published: 29 Desember 2021

\section{ABSTRAK}

Penelitian ini bertujuan untuk mengukur tingkat efisiensi OPZ di Indonesia periode 2017-2019. Penelitian ini menggunakan metode kuantitatif non parametrik dan mengumpulkan data dengan cara dokumentasi. Jenis data adalah data sekunder yang berupa laporan keuangan tahunan BAZNAS, Rumah Zakat, Dompet Dhuafa, ACT, dan PKPU periode 2017-2019. Ada dua variable input dan variable output. Variable input terdiri dari total aset dan biaya operasional, sedangkan variable output nya adalah penerimaan dana zakat dan penyaluran dana zakat. Berdasarkan penelitian yang telah dilakukan dengan metode DEA diperoleh hasil bahwa tahun 2017 lembaga yang tingkat efisiensi nya 100\% yaitu ACT, BAZNAS, dan Dompet Dhuafa, di tahun 2018 yaitu Dompet Dhuafa dan Rumah Zakat. Sedangkan di tahun 2019 adalah BAZNAS Dan Rumah Zakat. Pada tahun 2018 dan 2019 ACT mengalami penurunan nilai efisiensi yang cukup rendah, sedangkan dari tahun 2017-2020 PKPU tidak mencapai nilai $100 \%$ atau mengalami inefisiensi. Inefisiensi bisa diatasi dengan menetapkan target sesuai besaran yang ditetapkan pada perhitungan efisiensi DEA.

Kata Kunci : Efisiensi; OPZ; Kinerja; Data Envelopment Analysis.

\section{Abstract}

This study aims to measure the efficiency level of OPZ performance in Indonesia from 2017 to 2019 period. This study employed non-parametric quantitative methods, and the technique of data collection was documentation which was collected from secondary data, including annual financial reports of BAZNAS, Rumah Zakat, Dompet Dhuafa, ACT, and PKPU for the period 2017-2019. There were two variables i.e. input and output variables. The input variable consists of total assets and operational costs, while the output variable is the receipt and the distribution of zakat funds. According to the analysis result using DEA method, it shows that the institutions with efficiency levels of 100\% in 2017 were ACT, BAZNAS, and Dompet Dhuafa; Dompet Dhuafa and Rumah Zakat in 2018; and in 2019 were BAZNAS and Rumah Zakat. In 2018 and 2019, the efficiency values of ACT were relatively declined, while from 2017 to 2020 PKPU did not reach $100 \%$ or inefficiency. Inefficiency can be handled by setting targets according to the amount specified in the calculation of DEA scale efficiency.

Keywords: Efficiency; OPZ; Performance; Data Envelopment Analysis 


\section{PENDAHULUAN}

Keberadaan Indonesia sebagai negara berkembang tidak dapat terlepas dari banyaknya permasalahan di bidang ekonomi. Salah satu permasalahannyata yang dihadapi bangsa Indonesia adalah disparasi distribusi pendapatan dan kemiskinan (Analisa, 2015). Badan Pusat Statistik (BPS) mencatat garis kemiskinan di Indonesia turun 0,16 persen poin yaitu 410.670 per kapita perbulan pada bulan September 2018. Ini menurun terhadap bulan Maret 2018 dan menurun 0.46 persen poin terhadap bulan September 2017. (www.bps.go.id, 2019)

Zakat merupakan salah satu pondasi Islam yang berfungsi menjaga keseimbangan kehidupan (Sakti, 2002). Karena dalam syariat Islam, zakat dapat menciptakan keadilan ekonomi, kesejahteraan dan kemakmuran, sekaligus merupakan instrumen agar setiap muslim selalu peduli, serta memperhatikan sekelilingnya (Putra, 2019). Kehadiran zakat menjadi tiang penyangga infrastruktur sosial dalam membentuk masyarakat yang harmonis. (Said, 2014)

Zakat juga terbukti memiliki efek domino dalam kehidupan masyarakat, terutama membebaskan kaum dhuafa dari garis kemiskinan, meningkatkan pendapatan dan konsumsi masyarakat kecil. (Maulana et al., 2016)

Ada beberapa lembaga yang menerima titipan zakat, infaq dan sedekah di Indonesia yaitu Badan Amil Zakat Nasional (Baznas), Pos Keadilan Peduli Umat (PKPU), Aksi Cepat Tanggap, Dompet Dhuafa, dan Rumah Zakat (Hakim, 2020). Pada 2010, zakat yang diperoleh sekitar Rp. 217 triliun dan terus mengalami peningkatan di 2016 yang menyentuh angka Rp. 286 triliun (Fajarudin, 2019). Jika dibandingkan dengan dana yang dikeluarkan pemerintah pusat untuk menanggulangi kemiskinan, zakat dapat lebih efektif mengentaskan kemiskinan (Chaniago, 2015). Pemerintah menyalurkan Rp. 73,7 triliun tiap tahun untuk mengentaskan kemiskinan, sedangkan dengan zakat kita bisa membantu 1,7 juta mustahik tiap tahun yang merupakan sembilan persen dari warga miskin. (Fajarudin, 2019)

Dana zakat yang berhasil dikumpulkan masih jauh dari potensi yang telah disebutkan diatas. Dari potensi Rp. 217,3 triliun, penghimpunan zakat nasional hanya mencapai sekitar Rp. 1,7 triliun (Rahmayanti, 2014). Besarnya potensi zakat ini belum dibarengi dengan pengoptimalan penghimpunan maupun pendistribusian. Sehingga untuk mengetahui sejauh mana lembaga amil zakat mampu menghimpun dan menyalurkan dana Zakat, Infak, dan Sedekah (ZIS) yang terhimpun perlu adanya standar tata kelola yang baik dimana salah satu 
indikatornya adalah efisiensi dan efektifitas sebagai tolak ukur kinerja lembaga keuangan. (Lestari, 2015)

Efisiensi merupakan perbandingan antara keluaran (output) dengan masukan (input). Kemampuan menghasilkan output yang maksimal dengan input yang ada merupakan ukuran kinerja yang diharapkan. Pada saat pengukuran efisiensi dilakukan, lembaga keuangan dihadapkan pada kondisi bagaimana mendapatkan tingkat output yang optimal, dengan menganalisa alokasi input dan output, dapat dianalisa lebih jauh untuk melihat ketidakefisienan. (Muharam, 2007)

Bagi Organisasi Pengelola Zakat milik pemerintah maupun swasta, efisiensi merupakan suatu hal yang penting. Sehingga semakin efisien suatu organisasi pengelola zakat, maka semakin besar dampak positif pada pelaksanaan, pengumpulan, pengelolaan, dan distribusi zakat (Nafisatul, 2018). Efisiensi mutlak diperlukan bagi OPZ guna untuk mewujudkan maslahat yang lebih besar bagi umat. (Akbar, 2014)

Pengukuran efisiensi organisasi pengelola Zakat biasa menggunakan pendekatan intermediasi. Pendekatan interrmediasi merupakan pengukuran efisiensi yang merumuskan OPZ sebagai lembaga keuangan perantara antara pemilik dana kepada yang membutuhkan dana lembaga perantara, namun juga diukur dengan bagaimana kemampuan lembaga mengelola uang menjadi sejumlah aset-aset yang dimiliki untuk seperti banyaknya jumlah ambulan gratis, bangunan sekolah, bangunan rumah sakit, serta klinik yang disediakan untuk masyarakat. (Widyaningrum, 2018)

Diharapkan penelitian ini dapat mengukur efisiensi kinerja organisasi pengelola zakat (OPZ) di Indonesia. Agar mendapatkan hasil yang lebih efektif digunakan metode Data Envelopment Analysis. Sehingga dapat diketahui pospos operasional yang dapat ditingkatkan efisiensinya dan seberapa besar potensi dana terhimpun dan dana tersalurkan yang dapat dioptimalkan. Penelitian ini merupakan salah satu referensi bagi pengelola OPZ di Indonesia, sebagai bahan evaluasi terhadap kinerja yang telah dilakukan khususnya pada tahun 2017-2019 sehingga pengelola OPZ dapat mengetahui kinerjanya dan dapat meningkatkan kinerja lebih baik ke depannya

Efisiensi menurut Kamus Besar Bahasa Indonesia, adalah ketetapan cara (usaha, kerja) dalam menjalankan sesuatu dengan tidak membuang waktu, tenaga, dan biaya. Efisiensi juga dapat didefinisikan sebagai kemampuan organisasi untuk memaksimalkan output dengan menggunakan input tertentu atau menggunakan input secara minimal untuk menghasilkan output tertentu Efisensi adalah kemampuan untuk menyelesaikan suatu pekerjaan dengan benar atau dalam pandangan matematika di definisikan sebagai perhitungan rasio 
output (keluaran) dan atau input (masukan) atau jumlah keluaran yang dihasilkan dari suatu input yang digunakan. Secara sederhana efisiensi terdiri dari dua komponen yaitu Efisiensi Teknis mencerminkan kemampuan untuk menghasilkan output semaksimal mungkin dengan input yang ada, efisiensi secara teknis bukan berarti efisiensi secara alokatif. Efisiensi Alokatif Menggambarkan kemampuan untuk mengguanakan input dalam proporsi yang juga memasukkan perhitungan biaya. Decision Making Unit (DMU) dianggap efisien alokatif bila mampu menghasilkan output dengan biaya seminimal mungkin.

Efisiensi selalu dihubungkan dengan penggunaan sumber daya untuk mencapai suatu tujuan. Aktivitas dapat dikatakan efisien apabila dapat memperoleh hasil yang sama dengan aktivitas lain tetapi sumber daya yang digunakan lebih sedikit. Tingkat efisiensi diukur dengan mengguanakan indikator dari rasio antara nilai tambah (value added) dan nilai output. Ini berarti, semakin tinggi nilai rasio tersebut maka semakin tinggi pula tingkat efisiensinya.

\section{Pengukuran Efisiensi}

Ada tiga jenis pendekatan pengukuran efisiensi (Muharam, 2007) Pendekatan rasio yaitu pendekatan rasio dalam mengukur efisiensi dilakukan dengan menghitung perbandingan output dengan input yang digunakan. Pendekatan rasio akan dinilai memiliki efisiensi yang tinggi apabila dapat memproduksi jumlah output yang optimal dengan input yang seminimal mungkin.

$$
\text { Efisiensi }=\frac{\text { Output }}{\text { Input }}
$$

Kelemahan dari pendekatan ini adalah apabila terdapat banyak input dan output yang akan dihitung secara bersamaan, sehingga banyak perhitungan yang menimbulkan asumsi yang tidak tegas.

Pendekatan Regresi yaitu pendekatan ini mengukur efisiensi menggunaakan sebuah model dari tingkat output tertentu.

Persamaan regresi dapat ditulis sebagai berikut :

$$
Y=X_{1}+X_{2}+X_{3}+\cdots+X_{n}
$$

Dimana $Y$ adalah output dan $X$ adalah input. Perhitungan regresi ini tidak dapat mengakamodir jumlah variabel input yang banyak

Pendekatan Frontier pendekatan ini mempunyai dua jenis yaitu: parametric dan non-parametric. Pendekatan parametrik dapat diukur dengan tes statistik parametrik seperti menggunakan Stochastic Frontier Approach (SFA) dan Distribution Free Approach (DFA). Pendekatan frontier 
non-parametrik diukur dengan tes statistik non-parametrik yaitu dengan menggunakan Data Envelopment Analysis (DEA)

\section{Pengukuran Efisiensi Pada Organisasi Pengelola Zakat (OPZ)}

Organisasi Pengelola Zakat merupakan salah satu jenis dari organisasi nirlaba yang tidak berorientasi pada pencarian laba melainkan sebuah wadah yang bertujuan untuk mensejahterakan kehidupan social (Madania, Citra Aisya, 2016). Bagi para stakeholder organisasi nirlaba seperti badan amil zakat dan lembaga amil zakat, pengukuran efisiensi erat sekali dengan kinerja organisasi. Pengukuran kinerja dapat digunakan sebagai evaluasi atas akuntabilitas internal dan eksternal organisasi tersebut (Rahmayanti, 2014). Kinerja pada dasarnya adalah sebuah konsep multidimensi yang dapat berupa waktu, kualitas, inovasi efisiensi, efektivitas atau dimensi lain.

Bila sebuah lembaga menjalankan aktivitas tanpa melakukan pengukuran terhadap kinerja, maka lembaga tersebut tidak dapat melakukan perbaikan, meningkatkan pelayanannya, melakukan efisiensi, maupun memberikan perlakuan yang tepat kepada karyawannya (Gozali, 2005)

Ukuran-ukuran efisiensi organisasi nirlaba seperti BAZ/LAZ adalah sebagai berikut (Fathurrahman \& Hajar, 2019): Benefit, menyatakan ukuran keuangan dari nilai sosial yang dilekatkan pada jasa organisasi. Penilaian keuangan dari benefit mencakup dua komponen yaitu, pengeluaran sosial dan peningkatan pendapatan masyarakat (dalam lembaga amil zakat yang dimaksud masyarakat adalah mustahik). Outcome, menyatakan berbagai ukuran dari volume kegiatan tanpa memperhatikan apakah output tersebut mengarahkan organisasi pada outcome yang diharapkan. Contohnya jumlah mustahik yang diberdayakan. Input, menunjukkan ukuran non-keuangan dari jenis-jenis sumber daya yang digunakan organisasi. Cost, menunjukkan nilai keuangan dari semua sumber daya yang digunakan oleh organisasi untuk meningkatkan pelayanan jasanya

Efisiensi merupakan salah satu instrumen dalam mengukur kinerja lembaga yang memiliki laporan keuangan. Pengukuran efisiensi dilakukan dengan membandingkan input dengan output yang dihasilkan. Salah satu metode yang sering digunakan untuk menganalisis efisiensi adalah metode nonparametrik Data Envelopment Analysis (DEA). Dengan adanya analisis efisiensi ini maka dapat mengetahui mana yang lebih efisien dalam hal penggunaan input dan pengeluaran output.

Meode Pengukuran Efisiensi Dengan Metode Data Envelopment Analysis (DEA) 
Data Envelopment Analysis (DEA) adalah sebuah metode pengukur efisiensi yang menggunakan teknik pemrograman matematis. DEA mengukur efisiensi relatif dari kumpulan decision making unit (DMU) dalam mengelola sumber daya (input) dengan jenis yang sama sehingga menghasilkan output dengan jenis yang sama pula, dimana hubungan bentuk fungsi dari input ke output tidak diketahui (Siswadi \& Arafat, 2004)

DEA merupakan model pemrograman fraksional yang bisa mencakup banyak output dan input tanpa perlu menentukan bobot untuk tiap variabel sebelumnya, tanpa perlu penjelasan eksplisit mengenai hubungan fungsional antara input dan output (tidak seperti regresi). Pada dasarnya teknis analisis DEA didesain khusus untuk mengukur efisiensi relatif suatu Unit Kegiatan Ekonomi (UKE) dalam kondisi banyak input tersebut tidak dan output, di mana penggabungan input dan output mungkin dilakukan. (Lestari, 2015)

Data Envelopment Analysis, sesuai namanya merupakan metode yang mengelompokkan data observasi yang berbentuk frontier yang nantinya digunakan untuk mengevaluasi kinerja dari objek penelitian. DEA tidak hanya diguanakan untuk entitas bisnis tetapi bisa juga digunakan secara luas untuk bentuk organisasi-organisasi seperti sekolah. rumah sakit, yayasan dan lain-lain. (Lestari, 2015)

DEA merupakan pendekatan non-parametrik yang dipilih dalam penelitian ini karena beberapa alasan, pendekatan non-parametrik merupakan pendekatan yang modelnya tidak menetapkan syarat-syarat tertentu, yaitu parameter populasi yang menjadi induk sampel penelitiannya, penggunaannya lebih sederhana, dan mudah digunakan karena tidak membutuhkan banyak spesifikasi bentuk fungsi sehingga kemungkinan kesalalian pembentukkan fungsi lebih kecil (Afida, 2017)

\section{METODE PENELITIAN}

Penelitian ini merupakan jenis penelitian kuantitatif dengan pendekatan experimental, jenis data yang digunakan adalah data sekunder yang berupa laporan keuangan organisasi pengelola zakat selama 2017-2020 yang telah dipublikasikan. Populasi dari objek penelitian adalah Pengelola Zakat yang mempunyai Laporan keuangan dan Laporan Keuangan tersebut di publish ke khalayak umum. Pemilihan sampel dilakukan dengan teknik purposive sampling. 
Tabel 1. Sampling data OPZ

\begin{tabular}{cl}
\hline No & \multicolumn{1}{c}{ Nama Lembaga Organisasi Pengelola Zakat (Opz) } \\
\hline 1 & Badan Amil Zakat Nasional (BAZNAS) \\
\hline 2 & Rumah Zakat \\
\hline 3 & Dompet Dhuafa Republika \\
\hline 4 & Aksi Cepat Tanggap (ACT) \\
\hline 5 & Pos Keadilan Peduli Umat (PKPU) \\
\hline
\end{tabular}

\section{Teknik Pengumpulan Data}

Pengumpulan data yang dilakukan dalam penelitian ini adalah dokumentasi. Dokumentasi adalah proses pengumpulan data dengan mempelajari dan menganalisis dokumen-dokumen terkait seperti laporan keuangan Organisasi Pengelola Zakat (OPZ) periode 2017-2019.

\section{Identifikasi Variabel Input dan Output}

Mendefiniskan hubungan input output dalam tingkah laku dari institusi keuangan, penelitian ini menggunakan metode pendekatan produksi. Pendekatan produksi mengukur bagaimana kinerja OPZ dalam pengelolaan biaya guna menghasilkan penerimaan dana ziswaf serta penyaluran dana ziswaf yang efisien. Input yang digunakan adalah biaya operasional dan total asset

Output merupakan produk atau hasil langsung dari aktifitas program dan biasanya diukur dalam volume pekerjaan yang berhasil dicapai. Faktor-faktor output dalam organisasi pengelola zakat (OPZ) merupakan produk yang menjadi tujuan OPZ. Pengukuran output pada penelitian in diukur dari penerimaan dana dan penyaluran dana. Semakin banyak penerimaan dana berarti semakin banyak muzakki yang mempercayakan dana zakatnya kepada OPZ, sehingga mencerminkan kualitas aktivitas kinerja OPZ yang dilakukan sudah baik dan mencerminkan seberapa baik OPZ mensosialisasikan kinerja OPZ sebagai lembaga yang memiliki tugas utama untuk menghimpun dan mendistribusikan dana zakat dari dan untuk umat

Tabel 2. Variabel input dan Output penelitian

\begin{tabular}{cll}
\hline Pendekatan & \multicolumn{1}{c}{ Variabel Input } & Variabel Output \\
\hline Produksi & 1. Biaya Operasional & 1. Penerimaan Dana Zakat \\
& 2. Jumlah Aset & 2. Penyaluran Dana Zakat
\end{tabular}

Penelitian dengan metode Data Envelopment Analysis (DEA) ini menggunakan variabel input dan output. Variabel input terdiri dari total aset 
dan penerimaan dana zakat, sedangkan variabel outputnya terdiri dari biaya operasional dan penyaluran dana zakat. Berikut ini penjelasan dari masingmasing variable.

Total Aset, adalah aset keseluruhan, baik aset lancar maupun aset tidak lancar. Jumlah aset dinyatakan dalam satuan jutaan rupiah. Penerimaan Dana Zakat adalah total keseluruhan dana zakat yang berhasil dihimpun dari para muzakki oleh suatu lembaga dalam periode tertentu. Penyaluran Dana Zakat, adalah sejumlah dana zakat yang telah disalurkan kepada mustahik pada periode tertentu dalam bentuk program-program pemberdayaan maupun penyaluran langsung yang diberikan secara tunai

Penelitian ini menggunakan model variable return to scale (VRS) dengan pendekatan output. Pendekatan output digunakan ketika pasarnya masih luas dan perlu ditingkatkan agar mencapai tingkat efisiensi yang optimal, sedangkan penggunaan model VRS memungkinkan ruang analisis yang lebih beragam untuk menemukan solusi yang optimal. Hasil dari ini yaitu tidak ada unit yang akan menerima nilai efisiensi yang lebih rendah menggunakan VRS dari pada hasil model CRS. Setiap unit yang mengoperasionalkan dengan minimalisasi input atau memaksimalkan tingkat output, juga akan ditemukan efisien, menggunakan VRS dan juga jumlah total dari unit yang efisien $100 \%$ akan mungkin menjadi lebih tinggi.

\section{HASIL PENELITIAN DAN PEMBAHASAN}

\section{Tingkat efisiensi OPZ}

Suatu organisasi pengelola zakat (OPZ) dapat dikatakan memiliki kinerja yang tinggi apabila dapat menaikkan tingkat efisiensinya dengan menggunakan variabel-variabel yang akan memberikan hasil maksimal. perhitungan efisiensi OPZ dengan analisis DEA ini menggunakan pendekatan produksi untuk menentukan variabel input dan output nya. Variabel input terdiri dari Total aset, dan biaya operasional. Sedangkan untuk variabel output nya antara lain penerimaan zakat dan penyaluran zakat.

Sebuah organisasi pengelola zakat dikatakan efisien apabila nilainya mencapai angka $100 \%$ atau setara dengan 1 . Semakin ia menjauh dari angka 100 persen atau mendekati angka 0 persen, maka akan semakin tisak efisien. Suatu perusahaan dapat dikatakan efisien apabila mempergunakan jumlah unit input yang lebih sedikit dibandingkan jumlah input yang dipergunakan oleh perusahaan lain dengan menghasilkan output yang sama. Menggunakan jumlah unit input yang sama, tetapi menghasilkan output yang lebih besar. 
Pengukuran efisiensi dilakukan dengan memasukkan input dan output ke dalam software DEA untuk diolah menjadi nilai-nilai efisiensi. Berikut ini data dari laporan keuangan OPZ yang dijadikan variable input dan output:

Tabel 3. Input Penelitian

\begin{tabular}{lcccc}
\hline \multirow{2}{*}{ OPZ } & \multicolumn{3}{c}{ Input } \\
\cline { 2 - 5 } & \multicolumn{3}{c}{ Aset $(X 1)$} & BO $(X 2)$ \\
\hline 2019-BAZNAS & IDR & $110,044,770,250$ & IDR & $7,069,888,437$ \\
\hline 2019-Rumah Zakat & IDR & $25,924,403,170$ & IDR & $19,091,014,633$ \\
\hline 2019-Dompet Dhuafa & IDR & $332,080,602,007$ & IDR & $6,366,970,898$ \\
\hline 2019-ACT & IDR & $106,110,509,714$ & IDR & $30,849,850,395$ \\
\hline 2019-PKPU & IDR & $54,764,497,213$ & IDR & $21,020,535,875$ \\
\hline 2018-BAZNAS & IDR & $92,761,171,701$ & IDR & $5,859,319,100$ \\
\hline 2018-Rumah Zakat & IDR & $32,174,808,768$ & IDR & $16,148,554,154$ \\
\hline 2018-Dompet Dhuafa & IDR & $308,438,417,155$ & IDR & $5,692,996,084$ \\
\hline 2018-ACT & IDR & $65,437,589,009$ & IDR & $19,076,721,135$ \\
\hline 2018-PKPU & IDR & $49,398,359,504$ & IDR & $15,858,780,900$ \\
\hline 2017-BAZNAS & IDR & $60,822,688,145$ & IDR & $4,813,169,509$ \\
\hline 2017-Rumah Zakat & IDR & $28,629,073,474$ & IDR & $22,120,340,311$ \\
\hline 2017-Dompet Dhuafa & IDR & $300,021,549,887$ & IDR & $5,827,979,221$ \\
\hline 2017-ACT & IDR & $16,986,081,957$ & IDR & $15,022,922,560$ \\
\hline 2017-PKPU & IDR & $72,865,025,400$ & IDR & $21,850,499,069$ \\
\hline
\end{tabular}

Tabel 5. Output Penelitian

\begin{tabular}{lcccr}
\hline \multirow{2}{*}{ OPZ } & \multicolumn{4}{c}{ Output } \\
\cline { 2 - 5 } & \multicolumn{2}{c}{ PENERIMAAN ZAKAT } & \multicolumn{2}{c}{ PENYALURAN ZAKAT } \\
\hline 2019-BAZNAS & IDR & $138,096,290,551$ & IDR & $118,071,046,770$ \\
\hline 2019-Rumah Zakat & IDR & $113,382,621,377$ & IDR & $117,151,419,722$ \\
\hline 2019-Dompet Dhuafa & IDR & $146,273,657,234$ & IDR & $121,621,800,893$ \\
\hline 2019-ACT & IDR & $6,008,638,039$ & IDR & $8,341,610,622$ \\
\hline 2019-PKPU & IDR & $43,014,833,062$ & IDR & $28,568,908,549$ \\
\hline 2018-BAZNAS & IDR & $97,637,657,910$ & IDR & $67,727,019,807$ \\
\hline 2018-Rumah Zakat & IDR & $109,338,881,331$ & IDR & $57,491,277,593$ \\
\hline 2018-Dompet Dhuafa & IDR & $143,678,100,353$ & IDR & $155,184,810,852$ \\
\hline 2018-ACT & IDR & $4,614,514,622$ & IDR & $2,696,077,437$ \\
\hline 2018-PKPU & IDR & $7,850,410,298$ & IDR & $31,538,300,600$ \\
\hline 2017-BAZNAS & IDR & $82,272,643,293$ & IDR & $66,766,033,369$ \\
\hline
\end{tabular}




\begin{tabular}{llrlr}
\hline 2017-Rumah Zakat & IDR & $97,666,410,793$ & IDR & $91,612,583,464$ \\
\hline 2017-Dompet Dhuafa & IDR & $148,287,001,067$ & IDR & $155,969,431,267$ \\
\hline 2017-ACT & IDR & $2,594,266,277$ & IDR & $2,675,289,026$ \\
\hline 2017-PKPU & IDR & $44,955,955,051$ & IDR & $44,526,945,637$ \\
\hline
\end{tabular}

Setelah variabel input dan output ini diolah ke dalam DEA, maka dapat diketahui hasilnya. Berdasarkan hasil analisis menggunakan software MAXDEA dengan pendekatan BCC/VRS dan berorientasi pada variable output, dapat dilihat tingkat efsiensi OPZ pada table 4.2 hasil perhitungan menunjukan pencapaian OPZ tahun 2017-2019.

Tabel 6. Tingkat Efisiensi OPZ

\begin{tabular}{cll}
\hline NO & \multicolumn{1}{c}{ DMU } & \multicolumn{1}{c}{ Score } \\
\hline 1 & 2017-ACT & 1 \\
\hline 2 & 2017-BAZNAS & 1 \\
\hline 3 & 2017-Dompet Dhuafa & 1 \\
\hline 4 & $2017-$-PPU & 0.366982 \\
\hline 5 & $2017-$ Rumah Zakat & 0.855393 \\
\hline 6 & 2018-ACT & 0.036919 \\
\hline 7 & 2018-BAZNAS & 0.888666 \\
\hline 8 & 2018-Dompet Dhuafa & 1 \\
\hline 9 & 2018-PKPU & 0.268235 \\
\hline 10 & 2018-Rumah Zakat & 1 \\
\hline 11 & $2019-A C T$ & 0.064911 \\
\hline 12 & 2019-BAZNAS & 1 \\
\hline 13 & 2019-Dompet Dhuafa & 0.986423 \\
\hline 14 & 2019-PKPU & 0.352999 \\
\hline 15 & 2019-Rumah Zakat & 1
\end{tabular}

Tabel ini menunjukkan nilai efisiensi masing- masing DMU selama 3 tahun dengan data tahunan 2017 hingga 2019. Hasil analisis DEA, dapat diketahui bahwa DMU yang efisien sempurna (Constant 100\%) pada tahun 2017 adalah ACT, BAZNAS, dan Dompet Dhuafa. Pada tahun 2018 adalah Rumah Zakat dan Dompet Dhuafa, Sedangkan DMU yang efisien pada tahun 2019 adalah BAZNAS dan Rumah Zakat. Sehingga dapat disimpulkan bahwa Rumah Zakat pada tahun 2017 tingkat efisiensi rendah tetapi pada tahun 2018-2019 Rumah zakat dapat mempertahankan tingkat efisiensi.

Sedangkan BAZNAS pada tahun 2017 dan 2019 tingkat efisiensinya sempurna yaitu $100 \%$, tetapi tahun 2018 tingkat efisiensinya rendah yaitu $88.8 \%$. 
Kemudian Dompet dhuafa mempertahankan tingkat efisiensi di tahun 20172018, tetapi tahun 2019 tingkat efisiensinya menurun yaitu menjadi 98,6\%. Berdasarkan informasi tabel tersebut, DMU (OPZ) yang paling rendah angka efisiensinya adalah ACT pada tahun 2018 sebesar 3,6\% dan pada tahun 2019 sebesar $6 \%$. Hal ini tentunya dapat menjadi pertimbangan bagi DMU yang belum efisien untuk dapat meningkatkan efisiensi teknisnya (psure technical efficiency). Di samping itu, secara umum semua DMU yang berada di tengah- tengah tingkat efisiensi adalah sekitar 80\%-90\%.

Jika melihat OPZ yang belum efisien dapat diketahui dari tabel di atas bahwa DMU yang inefisien terbagi menjadi dua bagian yaitu Increasing Return to Scale (IRS) dan Decreasing Return to Scale (DRS). Adapun DMU yang termasuk dalam kelompok increasing yaitu Rumah Zakat (2017), BAZNAS (2018), dan Dompet Dhuafa Republika (2019). Demi mencapai tingkat efisien, DMU-DMU tersebut, masih dapat diusahakan perbaikan dengan melihat nilai potential improvementnya.

Berbeda halnya dengan DMU yang termasuk decreasing yaitu PKPU (2017), ACT (2018), PKPU (2018), ACT (2019), PKPU (2019) untuk mencapai efisien perlu menekan banyak biaya-biaya karena pasar telah jenuh dan sebagainya.

Skor Distribusi Efisiensi OPZ

Tabel 7. Skor Distribusi Efisiensi Organisasi Pengelola Zakat

\begin{tabular}{ll}
\hline \multicolumn{1}{c}{ DMU } & Score(VRS) \\
\hline 2017-ACT & 1 \\
\hline 2017-BAZNAS & 1 \\
\hline 2017-Dompet Dhuafa & 1 \\
\hline 2018-Dompet Dhuafa & 1 \\
\hline 2018-Rumah Zakat & 1 \\
\hline 2019-BAZNAS & 1 \\
\hline 2019-Rumah Zakat & 1 \\
\hline 2017-PKPU & 0.366982 \\
\hline 2017-Rumah Zakat & 0.855393 \\
\hline 2018-ACT & 0.036919 \\
\hline 2018-BAZNAS & 0.888666 \\
\hline 2018-PKPU & 0.268235 \\
\hline 2019-ACT & 0.064911 \\
\hline 2019-DKPU & 0.986423 \\
\hline
\end{tabular}


Pada tabel ini memberikan informasi jumlah unit organisasi pengelola zakat yang efisien dan tidak efisien pada skala kelompok tertentu. Berdasarkan tabel tersebut dapat diketahui jumlah DMU yang efisien sempurna (100\%) adalah sebanyak 7 DMU. Grafik di ini juga memberikan informasi bahwa unit bisnis terbanyak berada dalam kondisi efisiensi 85\%- 99\% yaitu sebanyak 3 DMU, sedangkan yang paling sedikit adalah. 3,6\%-6\% sebanyak 3 DMU dan Tingkat efisiensi $26 \%$ - 36\% sebanyak 2 DMU. Secara umum, DMU- DMU tersebut memiliki tingkat efisiensi yang relatif rendah karena ada yang mencapai tingkat efisiensi 3,6\%.

Analisis Referensi Unit

Tabel 8. Tabel Referensi Unit

\begin{tabular}{|c|c|c|c|}
\hline NO & DMU & Score & Benchmark (Lambda) \\
\hline 1 & 2017-ACT & 1 & 2017-ACT (1.000000) \\
\hline 2 & 2017-BAZNAS & 1 & 2017-BAZNAS (1.000000) \\
\hline 3 & 2017-Dompet Dhuafa & 1 & 2017-Dompet Dhuafa (1.000000) \\
\hline 4 & 2017-PKPU & 0.366982 & $\begin{array}{l}\text { 2017-Dompet Dhuafa (0.102398); 2019- } \\
\text { BAZNAS (0.224366); 2019-Rumah Zakat } \\
(0.673237)\end{array}$ \\
\hline 5 & 2017-Rumah Zakat & 0.855393 & $\begin{array}{l}\text { 2019-BAZNAS (0.032152); 2019-Rumah } \\
\text { Zakat (0.967848) }\end{array}$ \\
\hline 6 & 2018-ACT & 0.036919 & $\begin{array}{l}\text { 2019-BAZNAS (0.469722); 2019-Rumah } \\
\text { Zakat (0.530278) }\end{array}$ \\
\hline 7 & 2018-BAZNAS & 0.888666 & $\begin{array}{l}\text { 2017-BAZNAS (0.513306); 2017-Dompet } \\
\text { Dhuafa }(0.042018) ; 2019-\text { BAZNAS } \\
(0.444676)\end{array}$ \\
\hline 8 & 2018-Dompet Dhuafa & 1 & 2018-Dompet Dhuafa (1.000000) \\
\hline 9 & 2018-PKPU & 0.268235 & $\begin{array}{l}\text { 2017-Dompet Dhuafa (0.004720); 2019- } \\
\text { BAZNAS (0.263672); 2019-Rumah Zakat } \\
(0.731608)\end{array}$ \\
\hline 10 & 2018-Rumah Zakat & 1 & 2018-Rumah Zakat (1.000000) \\
\hline 11 & 2019-ACT & 0.064911 & $\begin{array}{l}\text { 2017-Dompet Dhuafa (0.292546); 2019- } \\
\text { Rumah Zakat (0.707454) }\end{array}$ \\
\hline 12 & 2019-BAZNAS & 1 & 2019-BAZNAS (1.000000) \\
\hline 13 & 2019-Dompet Dhuafa & 0.986423 & 2017-Dompet Dhuafa (1.000000) \\
\hline 14 & 2019-PKPU & 0.352999 & $\begin{array}{l}\text { 2019-BAZNAS (0.342843); 2019-Rumah } \\
\text { Zakat (0.657157) }\end{array}$ \\
\hline 15 & 2019-Rumah Zakat & 1 & 2019-Rumah Zakat (1.000000) \\
\hline
\end{tabular}


Tabel di atas menjelaskan tentang perbandingan DMU yang efisien dan yang belum efisien. DMU yang belum efisien untuk mencapai efisien dapat belajar atau meneladani DMU yang telah mencapai tingkat efisiensi sempurna $100 \%$.

\section{Analisis Benchmark DMU atau OPZ}

Tabel 9. Benchmark DMU Hasil Pengukuran Efisiensi dengan DEA

\begin{tabular}{lcc}
\hline \multicolumn{1}{c}{ DMU } & Score & $\begin{array}{c}\text { Times as a benchmark for } \\
\text { another DMU }\end{array}$ \\
\hline 2017-ACT & 1 & 0 \\
\hline 2017-BAZNAS & 1 & 1 \\
\hline 2017-Dompet Dhuafa & 1 & 5 \\
\hline 2017-PKPU & 0.366982 & 0 \\
\hline 2018-Rumah Zakat & 0.855393 & 0 \\
\hline 2018-ACT & 0.036919 & 0 \\
\hline 2018-BAZNAS & 0.888666 & 0 \\
\hline 2018-Dompet Dhuafa & 1 & 0 \\
\hline 2018-PKPU & 0.268235 & 0 \\
\hline 2018-Rumah Zakat & 1 & 0 \\
\hline 2019-ACT & 0.064911 & 0 \\
\hline 2019-BAZNAS & 1 & 6 \\
\hline 2019-Dompet Dhuafa & 0.986423 & 0 \\
\hline 2019-PKPU & 0.352999 & 0 \\
\hline 2019-Rumah Zakat & 1 & 6 \\
\hline
\end{tabular}

Bagian ini menunjukkan DMU yang menjadi rujukan atau referensi untuk DMU lainnya yang masih dalam kondisi inefisien. Dari hasil perhitungan analisis Max DEA menunjukkan bahwa pada tahun 2015 DMU yang paling banyak dirujuk adalah Dompet Dhuafa Republika sebanyak 5 DMU. Pada tahun 2016 tidak ada DMU yang dirujuk oleh DMU lainnya sebab tidakada DMU yang mencapai efisiensi sempurna pada tahun 2016. Sedangkan pada tahun 2017, DMU yang paling banyak dirujuk adalah BAZNAS sebanyak 6 DMU.

\section{KESIMPULAN}

Berdasarkan hasil penelitian ditemukan bahwa periode 2017 BAZNAS, ACT, dan Dompet Dhuafa tingkat efisiensi nya sudah mencapai $100 \%$ atau senilai dengan 1. Hal ini menunjukan BAZNAS, Rumah Zakat, dan Dompet 
Dhuafa sudah efisiensi secara maksmimal di tahun-tahun tersebut. Angka pada to gain $0,0 \%$ menunjukan target efisiensi sudah sesuai dengan kondisi actual dan memperoleh achieved 100\%. Di tahun 2016 Dompet Dhuafa dan Rumah Zakat tingkat efisiensi nya sudah mencapai $100 \%$ atau senilai dengan 1, ini menunjukan pada tahun tersebut Rumah Zakat dapat meningkatkan efisiensi nya dari tahun sebelum nya, dan Dompet Dhuafa tetap mempertahankan efisiensinya. Dan pada Tahun 2017 Rumah Zakat dan BAZNAS mencapai tingkat efisiensi 100\%, dan Dompet Dhuafa mengalami penurunan nilai efisiensi dari tahun sebelumnya. Untuk tahun 2016-2017 ACT mengalami penurunan tingkat efisiensi yang cukup rendah, sedangkan dari tahun 2015-2017 PKPU tidak mengalami efisiensi sempurna dikarenakan nilai nya yang kurang dari 100\%.

Inefisiensi pada tahun 2015 terjadi pada lembaga Rumah Zakat sebesar 85\% dan PKPU sebesar 36\%, di tahun 2016 inefisiensi terjadi pada BAZNAS sebesar 88,8 \%, ACT sebesar 3,6 \% dan PKPU sebesar $26 \%$. Tahun 2017 yang mengalami inefisiensi yaitu Dompet Dhuafa sebesar 98,6 \%, ACT sebesar 6,4 \% dan PKPU sebesar 32,5 \%. Inefisiensi ini desebabkan oleh input dan output tidak sesuai dengan target DEA. Ini dikarenakan asset yang kurang efektif, biaya operasional yang berlebihan seperti biaya publikasi dan dokumentasi, belanja karyawan dan lain-lain. Selain itu penerimaan zakat yang tinggi tetapi penyaluran zakat yang sedikit, terkadang terjadi kebalikan penerimaan zakat yang sedikit tetapi penyaluran zakat nya lebih tinggi dari seharusnya.

\section{DAFTAR PUSTAKA}

Afida, A. (2017). Analisis Efisiensi Badan Amil Zakat Nasional (BAZNAS) dalam Mengelola Dana Zakat dengan Metode Data Envelopment Analysis (DEA). UIN Syarif Hidayatullah Jakarta: Fakultas Ekonomi dan Bisnis, 2017.

Akbar, N. (2014). Analisis Efisiensi Organisasi Pengelola Zakat Nasional dengan Pendekatan Data Envelopment Analysis. Tazkia Islamic Finance and Business Review, 4(2).

Analisa, N. (2015). Pengaruh Pendayagunaan Zakat Produktif Terhadap Pendapatan Mustahiq (Studi Kasus pada LAZ PKPU Cabang Surabaya). Doktoral Disertasi. Universitas Brawijaya. 
Chaniago, S. A. (2015). Pemberdayaan zakat dalam mengentaskan kemiskinan. Jurnal Hukum Islam, 47-56.

Fajarudin, I. (2019). Kontribusi Zakat Sebagai Pendapatan Negara Dan Instrumen Penerimaan Pajak (Studi Interpretif). Paradigma Accountancy, Vol 2(No 1).

Fathurrahman, A., \& Hajar, I. (2019). Analisis Efisiensi Kinerja Lembaga Amil Zakat Di Indonesia. JES (Jurnal Ekonomi Syariah), 4(1).

Gozali, M. D. (2005). Communication Measurement (Konsep dan Aplikasi Kinerja Public Relation). Jakarta: PT Remaja Rosda Karya.

Hakim, R. (2020). Studi Komparatif Kriteria Amil Zakat, Hak dan Kewajibannya Pada Lembaga Amil Zakat Nasional (LAZNAS) Di Indonesia. ZISWAF: Jurnal Zakat Dan Wakaf, 7(1), 1-15.

Lestari, A. (2015). Efisiensi Kinerja Keuangan Badan Amil Zakat Daerah (BAZDA): Pendekatan Data Envelopment Analysis (DEA). Jurnal Ekonomi $\mathcal{E}$ Studi Pembangunan, 16(2), 177-187.

Madania, Citra Aisya, M. N. (2016). Pemahaman Maqashid Syariah (Akal) Terhadap Kinerja Lembaga Zakat Yatim Mandiri Di Surabaya. Jurnal Ekonomi Syariah Teori Dan Terapan, 3(3), 187.

Maulana, M. R., Hidayat, A. R., \& Malik, Z. A. (2016). Optimalisasi Pendayagunaan Dana Zakat Produktif Dalam Pemberdayaan Mustahiq Zakat Di Pkpu Kota Bandung. Prosiding Hukum Ekonomi Syariah, Spesia.

Muharam, H. (2007). Analisis Perbandingan Efisiensi Bank Syariah Di Indonesia Dengan Metode Data Envelopment Analysis (Periode tahun 2005). Jurnal Ekonomi Dan Bisnis Islam, 2(3), 80-166.

Nafisatul, F. (2018). Analisis Efisiensi Organisasi Pengelola Zakat Tingkat Nasional Dan Tingkat Daerah Kota Semarang Dengan Menggunakan Metode Data Envelopment Analysis. Universitas Wahid Hasyim Semarang.

Putra, T. W. (2019). Penghimpunan Dana Zakat Infak Dan Sedekah di Badan Amil Zakat Nasional. Laa Maisyir: Jurnal Ekonomi Islam, 6(2), 246-260.

Rahmayanti, A. (2014). Efisiensi Lembaga Amil Zakat dalam Mengelola Dana 
Zakat di Indonesia (Studi Kasus: PKPU, Rumah Zakat, dan BAMUIS BNI). Skripsi UIN Jakarta.

Said, H. A. (2014). Jalan panjang legislasi syariat zakat di Indonesia: Studi terhadap Undang-Undang Nomor 23 Tahun 2011 tentang pengelolaan zakat.

Sakti, A. (2002). Sistem Ekonomi Islam: Perspektif yang Terlupakan. Isefid Review, $1(1), 71-87$.

Siswadi, E., \& Arafat, W. (2004). Mengukur Efisiensi Relatif Kantor Cabang Bank dengan Menggunakan Metode Data Envelopment Analysis (DEA). Manajemen Usahawan, 1.

Widyaningrum, N. (2018). Efisiensi Organisasi Pengelola Zakat Nasional Di Indonesia Dengan Metode Data Envelopment Analysis. Jurnal Pendidikan Dan Ekonomi, 7(4), 316-325.

www.bps.go.id. (2019). Persentase Penduduk Miskin Pada September 2018 Sebesar 9,66 Persen. Bps.Go.Id. 